\section{Sciensage}

Journal of Advanced Scientific Research

Available online through https: / /sciensage.info
ISSN: 0976-9595

Short Communication

DOI: $10.55218 /$ JASR. 202213149

\title{
GROWTH PERFORMANCE OF CORIANDRUM SATIVUM L. INOCULATED WITH BIOFERTILIZERS-AN INITIAL STUDY
}

\author{
M. Yasmin Taj ${ }^{1}$, E. Mohan $*^{2}$ \\ ${ }^{1}$ Department of Microbiology, Ambiga College of Arts and Science for Women, Anna Nagar, Madurai, Tamil Nadu, India \\ ${ }^{2}$ Post Graduate and Research Department of Botany, Thiagarajar College, Teppakulam, Madurai, Tamil Nadu, India \\ *Corresponding author: easanmohan74@gmail.com
}

\begin{abstract}
Biofertilizers are cheap, eco-friendly, improve soil fertility and plant nutrition within short time, and are effective components in organic farming. The present field study was carried with eight treatments to study the effect of Azospirillum, Phosphobacterium and AM fungus and their combination on primary growth characters coriander. The experiment was conducted in a factorial randomized block design. The collar diameter, plant height and number of leaves were significantly more in treatment with combined inoculation of Azospirillum + Phosphobacterium + AM fungus $\left(\mathrm{T}_{7}\right)$ than control $\left(\mathrm{T}_{0}\right)$. The increase in primary growth parameters in treatments with biofertilizers may be due to enhance the uptake of nitrogen, phosphorous and other essential nutrients for the growth of coriander.
\end{abstract}

Keywords: Biofertilizers, Primary plant growth, Coriandrum sativum.

\section{INTRODUCTION}

Biofertilizers are beneficial microbial inoculants creating more attention in the context of sustainable agriculture. They contain living cells of different types of microorganisms that have an ability to convert nutritionally important elements from unavailable to available form through various biological processes and are known to help for better plant growth [1].

Coriander (Coriandrum sativum L.) belongs to Apiaceae family, and is having prime position in flavouring food, an important spice crop having pleasant aroma in the entire plant. Approximately 80 per cent of the world's total coriander seeds are produced in India, mainly cultivated in Northern states such as Rajasthan, Madhya Pradesh, Uttar Pradesh and Southern States such as Andhra Pradesh, Karnataka and Tamil Nadu [2].

It is essential to carry out the research at various sources for site specific nutrient management and to assess the efficacy of biofertilizer on the growth and yield of various crops include coriander. Based on the concerns mentioned above, present investigation was carried out to evaluate the impact of various biofertilizers on the primary growth of coriander.

\section{MATERIAL AND METHODS}

\subsection{Location of experiment}

The field experiment was carried out in Suranam which lies between $78.7186^{\circ}$ E longitude and $9.6929^{\circ} \mathrm{N}$ latitude at an altitude of $101 \mathrm{~m}$ above mean sea level in Sivagangai district of Tamil Nadu. This area receives the annual rainfall about 860.1-988.6 $\mathrm{mm}$. The temperature of this site fluctuates from $22^{\circ}-40^{\circ} \mathrm{C}$.

\subsection{Physico-chemical characteristics of experi- mental soil}

The physical characters such as texture, $\mathrm{pH}$ and electrical conductivity of soil obtained from $0-25 \mathrm{~cm}$ depth in the experimental field were analyzed by using standard procedures [3]. The chemical parameters includes the content of nitrogen, phosphorus, potassium, iron, manganese, zinc and copper were predicted by subjecting the standard methodologies [4].

\subsection{Treatments}

The biofertilizers used for this study are Azospirillum, Phosphobacterium and Arbuscular Mycorrhizal (AM) fungus and all these were procured from Department of Agricultural Microbiology, Agricultural College and Research Institute, Madurai. The treatments consist, $\mathrm{T}_{0}$ - control (without fertilizer), $\mathrm{T}_{1}$ - Azospirillum (15 gm), $\mathrm{T}_{2}$-Phosphobacterium (15gm), $\mathrm{T}_{3}$-AM fungus (15 gm), $\mathrm{T}_{4}$-Azospirillum + Phosphobacterium (7.5 gm each), $\mathrm{T}_{5}$ Azospirillum + AM fungus $(7.5 \mathrm{gm}$ each $), \mathrm{T}_{6}-$ Phosphobacterium + AM fungus (7.5 gm each) and $T_{7}$ - 
Azospirillum + Phosphobacterium + AM fungus $(5 \mathrm{gm}$ each). These treatments were replicated by three times in Randomized Block Design.

\subsection{Seed material}

The cultivar variety, Coriandrum sativum cv. $\mathrm{CO} 3$ was used for this study and seeds of this variety were obtained from the organic farmers of the study site, Suranam. The plots with the size of $2 \mathrm{~m} \times 2 \mathrm{~m}\left(4 \mathrm{~m}^{2}\right)$ were laid down for this study and $15 \mathrm{gm}$ seeds were hand sowed in each plot. Watering was done at the time of sowing and it was carried out regularly when soil moisture content was lower from $3^{\text {rd }}$ day after sowing. All the plots were kept weed-free by hand.

\subsection{Observations}

On $30^{\text {th }}$ day after sowing, 15 plants (five plant samples from each replication) were selected at random to record data on primary growth parameters like collar diameter, shoot length, root length, total length and number of leaves. The data was subjected to standard error analysis for ascertaining the responses to various treatments.

\section{RESULTS AND DISCUSSION}

\subsection{Physico-chemical characteristics of experimented soil}

The data regarding to various physico-chemical characters of soil of experimented field was highlighted in Table 1.

Table 1: Soil characteristics of the experimental field

\begin{tabular}{ccc}
\hline \multicolumn{3}{c}{ Physical characteristics } \\
\hline Parameters & Findings \\
\hline Soil texture & Sandy clay loam \\
\hline $\mathrm{pH}$ & \multicolumn{2}{c}{7.81} \\
\hline Electrical conductivity $\left(\mathrm{dS} \mathrm{m}^{-1}\right)$ & 0.15 \\
\hline \multicolumn{3}{c}{ Chemical characteristics } \\
\hline Parameters & Findings & $\begin{array}{c}\text { Fertility } \\
\text { level* }\end{array}$ \\
\hline Calcium carbonate & None & High \\
\hline Nitrogen $\left(\mathrm{kg} \mathrm{ac}^{-1}\right)$ & 172 & High \\
\hline Phosphorus $\left(\mathrm{kg} \mathrm{ac}^{-1}\right)$ & 11 & Middle \\
\hline Potassium $\left(\mathrm{kg} \mathrm{ac}^{-1}\right)$ & 259 & High \\
\hline Iron $(\mathrm{ppm})$ & 5.52 & Require \\
\hline Manganese $(\mathrm{ppm})$ & 4.62 & Require \\
\hline Zinc $(\mathrm{ppm})$ & 1.18 & Low \\
\hline Copper $(\mathrm{ppm})$ & 1.21 & Require \\
\hline $\begin{array}{l}\text { Note: } * \text { As per the data given by Soil Testing Laboratory, Madurai } \\
\text { (Department of Agriculture, Tamil Nadu State Government) }\end{array}$
\end{tabular}

The texture of experimental soil was sandy clay loam with $\mathrm{pH}$ of 7.81 and Electrical Conductivity of $0.15 \mathrm{dS}$ $\mathrm{m}^{-1}$. The soil consisted of $0 \%$ calcium carbonates and it was having high fertility in respect of nitrogen $(172 \mathrm{~kg}$ $\mathrm{ac}^{-1}$ ), and medium fertility with respect to phosphorus $\left(11 \mathrm{~kg} \mathrm{ac}^{-1}\right)$ and high fertility with potassium $\left(259 \mathrm{~kg} \mathrm{ac}^{-1}\right)$. The soil sample also contained 4.52ppm level of iron (require fertile level), $4.62 \mathrm{ppm}$ of manganese (require fertile level), $1.18 \mathrm{ppm}$ of zinc (low fertile level) and $1.21 \mathrm{ppm}$ of copper (require fertile level).

\subsection{Primary growth response of coriander to biofertilizers}

By the current experiment, it was predicted that all the biofertilizers treated coriander plants recorded significant differences when compared to untreated plants (Table 2 \& Fig. 1). In case of caller diameter, there was no significant difference observed among the treated plants except untreated ones. It was recorded that $9.0 \mathrm{~mm}$ of collar diameter as highest in $\mathrm{T}_{7}$ (Azospirillum + Phosphobacterium + AM fungus), $\mathrm{T}_{1}$ (Azospirillum), $\quad \mathrm{T}_{2} \quad$ (Phosphobacterium) and $\mathrm{T}_{4}$ (Azospirillum + Phosphobacterium) plants. The highest plant height $(13.22 \mathrm{~cm})$ and number of leaves (7.75) were found in the coriander plants treated with Azospirillum + Phosphobacterium + AM fungus $\left(\mathrm{T}_{7}\right)$. Overall, the primary growth parameters such as collar diameter, plant height and number of leaves were increased by the combined application of Azospirillum + Phosphobacterium + Am fungus $\left(\mathrm{T}_{7}\right)$ when compare to untreated control plants (Table 2 \& Fig. 1).

These results are in agreement with those found by Amin [5], Aishwath et al. [6], Mounika et al. [7] and Özyazici [8]. They have also observed that the growth and yield parameters of coriander such as plant height, number of branches, number of umbels, seed yield, the biological yield, harvest index and essential oil yield were increased with the application Azospirillum, phosphate solubilizing bacteria and other organic fertilizers by individual or combined application.

The reason behind the increase in growth of coriander is due to the phytohormones synthesized by Azospirillum, which simulates growth and induce changes in root morphology in turn influencing assimilation of nutrients [9]. The enhanced growth $C$. sativum plants in the present work also could be attributed to the importance of Phosphobacterium as they solubilize the insoluble phosphorus for the uptake of plants to their growth and development [6]. The results of the present study also revealed that the application of biofertilizers along with 
AM fungus showed improved growth in coriander and this phenomenon was already reported by Mohan and Rajendran [10] and this may be due to the improvement of uptake of mineral nutrients thus enhance the plant growth. The maximum plant growth could also be attributed to the availability of atmospheric nitrogen and soil phosphorus as a result of combined microbial inoculation, have led to better root and shoot development, better uptake of water, nutrients and their transportation [11].

Table 2: Effect of different biofertilizers on growth of coriander

\begin{tabular}{cccccc}
\hline \multirow{2}{*}{ Treatments } & \multicolumn{5}{c}{ Growth parameters } \\
\cline { 2 - 6 } & $\begin{array}{c}\text { Collar diameter } \\
(\mathbf{m m})\end{array}$ & $\begin{array}{c}\text { Shoot length } \\
\mathbf{( \mathbf { c m } )}\end{array}$ & $\begin{array}{c}\text { Root length } \\
\mathbf{( \mathbf { c m } )}\end{array}$ & $\begin{array}{c}\text { Total length } \\
\mathbf{( \mathbf { c m } )}\end{array}$ & $\begin{array}{c}\text { Number of } \\
\text { leaves }\end{array}$ \\
\hline $\mathrm{T}_{0}$ & $0.5 \pm 0$ & $5.10 \pm 0.25$ & $3.10 \pm 0.11$ & $8.20 \pm 0.28$ & $5.50 \pm 0.57$ \\
\hline $\mathrm{T}_{1}$ & $0.9 \pm 0.08$ & $7.55 \pm 0.47$ & $5.37 \pm 0.20$ & $12.92 \pm 0.66$ & $6.75 \pm 0.50$ \\
\hline $\mathrm{T}_{2}$ & $0.9 \pm 0$ & $7.32 \pm 0.49$ & $4.72 \pm 0.49$ & $12.04 \pm 0.90$ & $6.50 \pm 0.57$ \\
\hline $\mathrm{T}_{3}$ & $0.7 \pm 0$ & $7.40 \pm 0.36$ & $4.12 \pm 0.17$ & $11.52 \pm 0.53$ & $5.75 \pm 0.95$ \\
\hline $\mathrm{T}_{4}$ & $0.9 \pm 0$ & $7.57 \pm 0.37$ & $5.15 \pm 0.12$ & $12.62 \pm 0.33$ & $6.25 \pm 0.50$ \\
\hline $\mathrm{T}_{5}$ & $0.87 \pm 0.05$ & $7.65 \pm 0.34$ & $5.40 \pm 0.29$ & $13.05 \pm 0.61$ & $7.25 \pm 0.87$ \\
\hline $\mathrm{T}_{6}$ & $0.85 \pm 0.05$ & $7.50 \pm 0.25$ & $5.15 \pm 0.12$ & $12.65 \pm 0.38$ & $7.00 \pm 0.81$ \\
\hline $\mathrm{T}_{7}$ & $1.0 \pm 0$ & $7.90 \pm 0.77$ & $5.32 \pm 0.28$ & $13.22 \pm 0.99$ & $7.75 \pm 0.95$ \\
\hline
\end{tabular}

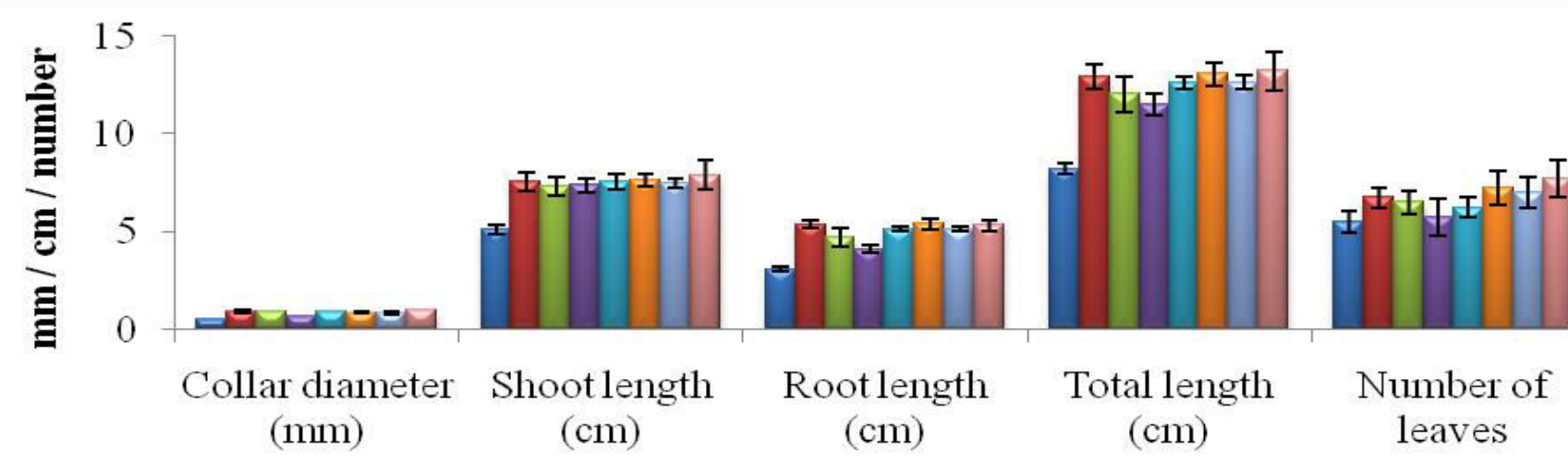

Growth parameters

\section{T0 $\square \mathrm{T} 1 \square \mathrm{T} 2 \square \mathrm{T} 3 \square \mathrm{T4} \square \mathrm{T} 5 \square \mathrm{T} 6 \square \mathrm{T} 7$}

$T_{1}$ - Azospirillum, $T_{2}$ - Phosphobacterium, $T_{3}-A M$ fungus, $T_{4}$ - Azospirillum + Phosphobacterium, $T_{5}-$ Azospirillum + AM fungus, $T_{6}-$ Phosphobacterium $+A M$ fungus and $T_{7}$-Azospirillum + Phosphobacterium $+A M$ fungus

Fig. 1: Effect of biofertilizers on primary growth of coriander

\section{CONCLUSION}

Further researches are needed to evaluate the efficacy of biofertilizers on the growth and yield parameters of coriander in large scale. Form the results of present study, it can be concluded that, coriander crop positively responded to biofertilization, especially combined inoculation of Azospirillum, Phosphobacterium and AM fungus. Although chemical fertilizers achieved the greatest results in term of the properties assessed in our study, when considering soil fertility and environment, biofertilizers can be used partially or completely instead of chemical fertilizers.

\section{Conflict of interest}

The authors have declared that there is no conflict of interest.

\section{REFERENCES}

1. Vessey JK. Plant Soil, 2003; 255:571-586.

2. Aishwath OP, Singh HR, Velmurugan A, Anwer MM. Int. J. Seed Spices, 2011; 1(1):29-37.

3. Piper CS. Soil and plant analysis, Asia Publishing House, Bombay, 1966.

4. Jackson ML. Soil Chemical Analysis, Prentice-Hall of India, Pvt. Ltd., New Delhi, 1973. 
5. Amin IS. Ann. Agri. Sci., 1997; 35(4):2327-2334.

6. Aishwath OP, Lal G, Kant K, SharmaYK, Ali SF, Naimuddin S. Int. J. Seed Spices, 2012; 2(2):9-14

7. Mounika Y, Thanuja Sivaram G, Syam Sundar Reddy P, Ramaiah M. J. Hortl. Sci., 2017; 12(2): 113-117.
8. Özyazici G. Agronomy, 2021; 11:1427.

9. Summer ME. Adv. Soil Sci., 1990; 12:53-123.

10. Mohan E, Rajendran K. Int. J. Curr. Microbiol. Appl. Sci., 2014; 3(7):103-116.

11. Rahimi AR, Mashayekhi K, Amini S, Soltani E. Med. Arom. Plant Sci. Biotechnol., 2009; 3:21-23. 